\title{
Skin Response Observation Object
}

National Cancer Institute

\section{Source}

National Cancer Institute. Skin Response Observation Object. NCI Thesaurus. Code C117676.

The name of the entity that is being assessed in a skin response examination. 